\title{
Response to Low Cardiac Output: Developmental Differences in Metabolism during Oxygen Deficit and Recovery in Lambs
}

\author{
JOHN T. FAHEY AND GEORGE LISTER \\ Departments of Pediatrics and Anesthesiology, Yale University School of Medicine, \\ New Haven, Connecticut 06510
}

\begin{abstract}
When cardiac output is critically lowered, whole body $\mathrm{O}_{2}$ consumption decreases and an $\mathrm{O}_{2}$ deficit accumulates. With restoration of cardiac output, an excess $\mathrm{O}_{2}$ consumption is expected in order to "repay" some or all of the $\mathrm{O}_{2}$ deficit. We tested the hypothesis that young lambs, with higher resting $\mathrm{O}_{2}$ consumption, cardiac output and growth rates than older lambs, would repay less of their $\mathrm{O}_{2}$ deficit because they have a higher proportion of nonessential metabolism. We reduced cardiac output acutely by inflating a Foley catheter in the right atrium of spontaneously breathing, sedated lambs at ages $2(n=5)$ and $8(n=5)$ wk. Each lamb was studied with low cardiac output periods of 30 and $60 \mathrm{~min}$ on different days. Aortic and pulmonary artery blood pressures, gases, and $\mathrm{O}_{2}$ saturations, venous $\mathrm{Hb}$, and arterial lactate concentrations were measured every 10 min during baseline, low output, and $60 \mathrm{~min}$ of recovery. Oxygen consumption was monitored continuously. Oxygen deficit and excess $\mathrm{O}_{2}$ of recovery were calculated from the time integral of the difference between $\mathrm{O}_{2}$ consumption at baseline and during the respective study period. The average percent decreases in cardiac output (66.4 and $64.6 \%)$ and $\mathrm{O}_{2}$ consumption (38.1 and $35.1 \%$ ) were similar in the 2 - and 8-wk groups, respectively. There was no consistent relation between $\mathrm{O}_{2}$ deficit and $\mathrm{O}_{2}$ repayment in either age group. However, on average the 2-wk group repaid a significantly lower percentage $(3 \pm 16 \%$, mean \pm SEM) than 8-wk-olds ( $76 \pm$ $29 \%$ ). Moreover, lactate increased linearly with time and $\mathrm{O}_{2}$ deficit in both age groups, but lactate accumulated at a significantly lower rate in the 2-wk as compared to the 8wk group for comparable deficits. We speculate that, during periods of very low cardiac output, 2-wk-old lambs not only decrease $\mathrm{O}_{2}$ consumption, but also decrease metabolic demands, possibly by suppressing nonessential metabolism. This results in fewer energy stores that need to be replenished during recovery. This is a potential mechanism for the greater tolerance of young animals to hypoxic stresses. (Pediatr Res 26: 180-187, 1989)
\end{abstract}

When $\mathrm{O}_{2}$ supply to the tissues is critically reduced by hypoxemia, anemia, or low cardiac output, whole body $\mathrm{O}_{2}$ consumption decreases and an $\mathrm{O}_{2}$ deficit accumulates throughout the hypoxic period (1-3). With restoration of $\mathrm{O}_{2}$ supply, there is a

Received November 3, 1988; accepted May 11, 1989.

Correspondence John T. Fahey, Department of Pediatrics, Yale University School of Medicine, 333 Cedar Street, New Haven, CT 06510.

Supported by a grant from the American Heart Association and the Connecticut Heart Affiliate. G. L. is an Established Investigator of the American Heart Association. transient excess in $\mathrm{O}_{2}$ consumption above the initial baseline level and it has been suggested that this excess represents "repayment" of some or all of the $\mathrm{O}_{2}$ deficit $(4,5)$ in a manner analogous to exercise (6). However, in studies of hypoxic hypoxia by Adams and Cain (5) in adult dogs, it was observed that there was neither "repayment" of all nor of a fixed proportion of the $\mathrm{O}_{2}$ deficit. From this and other work they suggested that the fraction of the deficit not repaid was due to oxidative processes that were reduced or turned off during the period of hypoxia and thus represented nonessential, or "facultative," metabolism.

During studies in our laboratory in which $\mathrm{O}_{2}$ delivery was reduced by selectively lowering cardiac output, we noted that young lambs had minimal, if any, transient excess $\mathrm{O}_{2}$ consumption after restoration of $\mathrm{O}_{2}$ supply, yet older lambs seemed to have a considerable excess in $\mathrm{O}_{2}$ consumption for a period of time. It was our hypothesis that young lambs with a higher resting $\mathrm{O}_{2}$ consumption, surface area to mass ratio, and growth rate than their older counterparts would repay less of an $\mathrm{O}_{2}$ deficit because they have a higher proportion of metabolism devoted to nonessential processes. To test this, in our study we examined the relationship between $\mathrm{O}_{2}$ deficit and excess $\mathrm{O}_{2}$ of recovery under conditions of critically low cardiac output and determined whether this relationship varied as a function of age or with the degree of $\mathrm{O}_{2}$ deficit. In addition, we compared the rate of lactate accumulation with respect to $\mathrm{O}_{2}$ deficit to determine whether the deficit induced comparable degrees of tissue hypoxia at each age.

\section{MATERIALS AND METHODS}

Subjects. All animals studied were healthy lambs. We studied five lambs at 2 wk after birth (mean $18 \mathrm{~d}$, range 13-21 d), a time of rapid growth when resting $\mathrm{O}_{2}$ consumption and cardiac output are high, and five lambs at 8 wk (mean $57 \mathrm{~d}$, range 54-66 d), when resting $\mathrm{O}_{2}$ consumption and cardiac output have declined to near adult values (7). Four lambs were studied at both 2 and $8 \mathrm{wk}$ of age. One lamb was studied only at $2 \mathrm{wk}$; another lamb was studied only at $8 \mathrm{wk}$ of age.

Preparation. The lamb was sedated with intramuscular ketamine $(10 \mathrm{mg} / \mathrm{kg}$ intramuscularly). Using local lidocaine analgesia and sterile technique, catheters were placed by means of an incision over the respective blood vessel. An arterial catheter was advanced from the hindleg to a distance estimated to reach the descending thoracic aorta. A balloon-tipped, end-hole venous catheter was advanced from the leg into the pulmonary artery, monitoring pressure to ensure proper placement. After this, a jugular vein was isolated through a small incision in the neck. A Foley catheter was inserted and advanced to the right atrium; again the pressure tracing was monitored to ensure proper placement. We have previously described a method to lower cardiac output in conscious lambs by placing a balloon-tipped (Foley) 
catheter into the right atrium (8). Balloon inflation limits venous return and therefore lowers cardiac output. In previous observations, we found that balloon inflation causing very low levels of cardiac output raised inferior vena caval pressure only slightly, to the range of 6 to $8 \mathrm{~mm} \mathrm{Hg}$. In those studies, remarkably high levels of tissue $\mathrm{O}_{2}$ extraction $(0.90$ to 0.95$)$ were obtained suggesting that there was no tissue engorgement. Subsequent balloon deflation allows immediate restoration of venous return and cardiac output. Usually a catheter with $5 \mathrm{~mL}$ balloon volume was used for the younger lambs and $30 \mathrm{~mL}$ volume for the older subjects.

All catheters were sutured in place, and the lamb was placed upright in a sling. To test adequacy of placement of the Foley catheter, the Foley balloon was inflated with warmed saline to determine the volume necessary to lower arterial blood pressure by approximately $50 \%$. The balloon was then deflated, and all catheters were flushed with heparinized saline, plugged, and fastened out of the reach of the animal. The lamb was then returned to the animal quarters and allowed to recover overnight. All lambs were given $400000 \mathrm{U}$ penicillin $\mathrm{G}$ procaine and 500 $\mathrm{mg}$ dehydrostreptomycin intramuscularly, for $3 \mathrm{~d}$ after the surgery. All lambs recovered from surgery for 24 to $96 \mathrm{~h}$ before study.

Experimental protocol. At 2 and 8 wk each lamb underwent two studies, one for $30 \mathrm{~min}$ of low cardiac output and another for $60 \mathrm{~min}$ of low cardiac output. The order was randomized and the studies were separated by at least $24 \mathrm{~h}$.

At each study the lamb was removed from its pen, weighed, and then placed in a sling so that it was supported in an upright position. The lamb was blindfolded in an attempt to keep it calm. The lamb's snout was then secured in a mask to permit room air to be drawn in and expired gases to be collected for measurement of $\mathrm{O}_{2}$ consumption and $\mathrm{CO}_{2}$ production. All lambs were given ketamine $10 \mathrm{mg} / \mathrm{kg}$ intramuscularly followed immediately by continuous intravenous infusion at $10 \mathrm{mg} \mathrm{kg}^{-1} \mathrm{~h}^{-1}$. Ketamine was used to sedate the lambs to maintain a stable baseline $\mathrm{O}_{2}$ consumption. We have found in previous studies that this dose of ketamine does not change the mean resting $\mathrm{O}_{2}$ consumption but prevents agitation and wide variations in $\mathrm{O}_{2}$ consumption associated with external disturbances.

The aortic, pulmonary arterial and Foley catheters were connected via sampling stopcocks to pressure transducers (Statham P23Db, Gould Statham, Hato Rey, Puerto Rico) so that each pressure was monitored and recorded separately on a Beckman multichannel recorder (R611) (Beckman Instruments, Inc., Fullerton, $\mathrm{CA}$ ).

During the study, $\mathrm{O}_{2}$ consumption and $\mathrm{CO}_{2}$ production were monitored continuously and recorded on a strip chart recorder. Additional data were collected every $10 \mathrm{~min}$ throughout the study (baseline, low cardiac output, and recovery periods). Systolic, diastolic and electronically derived mean pressures were recorded from the aorta and pulmonary artery at a rapid paper speed. Heart rate was measured from the aortic pressure trace. Blood samples ( 0.5 to $0.7 \mathrm{~mL} / \mathrm{sample})$ were slowly withdrawn from the aortic catheter (for blood gas tensions, $\mathrm{pH}, \mathrm{Hb} \mathrm{O}_{2}$ saturation, and lactate and pyruvate determination) and from the pulmonary arterial catheter (for blood gas tensions, $\mathrm{pH}, \mathrm{Hb}$ $\mathrm{O}_{2}$ saturation, $\mathrm{Hb}$ concentration and hematocrit). The blood removed was replaced with an equal volume of normal saline. (In previous studies with prolonged right atrial balloon inflation, we found that the $\mathrm{Hb}$ concentration tended to increase slightly with time. As we were attempting to lower cardiac output without changing $\mathrm{Hb}$ concentration or arterial oxygen content, we elected to replace the blood drawn with normal saline and not blood.) Rectal and ambient temperatures were recorded every $10 \mathrm{~min}$.

After the lamb had stabilized during the ketamine infusion and $\mathrm{O}_{2}$ consumption was relatively constant, data (as above) were obtained during a 20 to 30 -min baseline period. Then a period of low cardiac output was abruptly induced by inflation of the right atrial balloon to a level sufficient to reduce $\mathrm{O}_{2}$ consumption by approximately $30 \%$ and blood pressure by approximately $50 \%$. The period of low cardiac output was continued for 30 or $60 \mathrm{~min}$ and then the balloon was abruptly deflated allowing restoration of blood flow and recovery. Data were then obtained for $60 \mathrm{~min}$ of recovery. After this, the ketamine infusion was discontinued, the catheters were flushed and secured, and the lambs returned to the animal quarters for subsequent study. At the end of the studies at $2 \mathrm{wk}$, all catheters were removed and the lambs were returned with their ewes to the animal facilities. For the four lambs from this group restudied at $8 \mathrm{wk}$ of age, catheters were placed (as described above) in vessels from the limbs or neck opposite to those used at $2 \mathrm{wk}$. No complications of recatheterization were encountered.

Measurements. Oxygen consumption and $\mathrm{CO}_{2}$ production were measured by a flow-through system in which ambient air was drawn at a constant rate through a face mask and was mixed with expired gas from the nose and mouth. The fractional concentrations of $\mathrm{O}_{2}$ and $\mathrm{CO}_{2}$ were monitored continuously for calculation of $\mathrm{O}_{2}$ consumption and $\mathrm{CO}_{2}$ production as described previously $(3,9)$. Blood gas tensions and $\mathrm{pH}$ were measured by standard electrodes at $37^{\circ} \mathrm{C}$ (Radiometer America Inc., Westlake, $\mathrm{OH}$ ) and corrected to body temperature. $\mathrm{Hb} \mathrm{O}_{2}$ saturation was measured using a microoximeter (Radiometer OSM2). Hb concentration was measured by the cyanmethemoglobin method. Hematocrit was determined by use of a microhematocrit centrifuge. Lactate and pyruvate concentrations were determined using an enzymatic method (Sigma Chemical Co., St. Louis, MO) (10).

Calculations. Arterial and mixed venous blood $\mathrm{O}_{2}$ contents $\left(\mathrm{CaO}_{2}, \mathrm{CV}_{2}\right.$, in $\left.\mathrm{mL} \mathrm{O} / \mathrm{dL}\right)$ were calculated from the $\mathrm{PO}_{2}(\mathrm{~mm}$ $\mathrm{Hg}$ ), fractional $\mathrm{HbO}_{2}$ saturation, and $\mathrm{Hb}$ (in $\mathrm{g} / \mathrm{dL}$ ) as:

$$
\mathrm{CaO}_{2}, \mathrm{CV}_{2}=\left(1.36 \times \mathrm{Hb} \times \mathrm{Hb} \mathrm{O}_{2}\right)+\left(0.003 \times \mathrm{PO}_{2}\right)
$$

where $0.003 \mathrm{~mL} \mathrm{O}_{2} / \mathrm{dL}_{\text {plasma }}{ }^{-1} \mathrm{~mm} \mathrm{Hg}^{-1}$ is the Bunsen solubility coefficient for $\mathrm{O}_{2}$ in plasma at $37^{\circ} \mathrm{C}$.

Cardiac output $\left(\mathrm{CO}\right.$, in $\mathrm{mL} \mathrm{min}{ }^{-1} \mathrm{~kg}^{-1}$ ) indexed to animal wt was calculated using the Fick equation, from $\mathrm{O}_{2}$ consumption $\left(\dot{\mathrm{VO}}_{2}\right.$, in $\left.\mathrm{mL} \min ^{-1} \mathrm{~kg}^{-1}\right), \mathrm{CaO}_{2}$, and $\mathrm{Cv}_{2}$ as:

$$
\mathrm{CO}=\left[\dot{\mathrm{VO}}_{2} /\left(\mathrm{CaO}_{2}-\mathrm{C}_{\mathrm{v}} \mathrm{O}_{2}\right)\right] \times 100
$$

Fractional $\mathrm{O}_{2}$ extraction was defined as:

$$
\mathrm{O}_{2} \text { extraction }=\left(\mathrm{CaO}_{2}-\mathrm{Cv}_{2}\right) / \mathrm{CaO}_{2}
$$

Total systemic resistance was calculated as the quotient of mean aortic pressure (MAP) and cardiac output:

$$
\text { total systemic resistance }=\mathrm{MAP} / \mathrm{CO}
$$

We did not monitor superior or inferior vena caval pressures. In fact, these pressures may be different from each other during right atrial balloon inflation. However, in earlier studies, we found that inferior vena caval pressures increased by only 3 to 5 $\mathrm{mm} \mathrm{Hg}$ with comparable levels of balloon inflation. We therefore calculated total systemic vascular resistance (above) as our best estimate of changes in systemic vascular resistance during balloon inflation and recovery.

In order to determine the $\mathrm{O}_{2}$ deficit of the tissues, the average baseline $\mathrm{O}_{2}$ consumption was determined from the stable 20 to 30 -min period proceeding the reduced cardiac output. The assumption was made that if the period of low cardiac output had not occurred, the tissue $\mathrm{O}_{2}$ consumption would have remained constant from baseline to the end of the recovery period. The $\mathrm{O}_{2}$ deficit was the integral with respect to time of the difference between the expected tissue $\mathrm{O}_{2}$ consumption (i.e. the extrapolated baseline) and the tissue $\mathrm{O}_{2}$ consumption measured during the period of low cardiac output. Similarly, the excess $\mathrm{O}_{2}$ consumption of recovery was the time integral between the $\mathrm{O}_{2}$ consumption during recovery and the extrapolation of the baseline value. For these calculations, we also accounted for changes in body stores of $\mathrm{O}_{2}$ (in the lungs, tissue water, and blood) that take place during the transition from baseline to low cardiac 
output, and then from low cardiac output to recovery (2). Changes in myoglobin stores were not accounted for as this compartment has been assessed to be quite small (4), amounting to less that $1 \mathrm{~mL} / \mathrm{kg}$ of muscle (5). While the quantity of stored $\mathrm{O}_{2}$ is changing and reaching a new level, the $\mathrm{O}_{2}$ consumption measured at the mouth is transiently different than the actual tissue $\mathrm{O}_{2}$ consumption. Because only $\mathrm{O}_{2}$ extracted from the atmosphere is measured at the mouth (i.e. the difference between inspired and expired $\mathrm{O}_{2}$ ), correction of the measured $\mathrm{O}_{2}$ consumption by the change in stores should yield the actual tissue $\mathrm{O}_{2}$ consumption.

$\mathrm{O}_{2}$ stores in the lung were estimated as:

$\left[\left(\mathrm{PAO}_{2}(@ \mathrm{~B}, \mathrm{E}\right.\right.$, or $\left.\left.\mathrm{R})\right) /\left(\mathrm{P}_{\mathrm{B}}-\mathrm{P}_{\mathrm{H}_{2} \mathrm{O}}\right)\right] \times(30 \mathrm{~mL} / \mathrm{kg})$

$$
\times \mathrm{wt}=\mathrm{mL} \mathrm{O}_{2} \mathrm{STPD}
$$

where $\mathrm{PAO}_{2}(\mathrm{~mm} \mathrm{Hg})$ was determined by the alveolar gas equation; $\mathrm{B}$ represents the average value during the baseline period, $E$ during the experimental period of low cardiac output, and $R$ during the recovery period; $\mathrm{P}_{\mathrm{B}}$ and $\mathrm{P}_{\mathrm{H}_{2} \mathrm{O}}$ were barometric pressure and water vapor pressure $(\mathrm{mm} \mathrm{Hg})$; and the value $30 \mathrm{~mL} / \mathrm{kg}$ represents the estimated average functional residual capacity of lambs as measured in our laboratory in unrelated studies (PérezFontán JJ, Personal communication) and wt is in $\mathrm{kg}$.

$\mathrm{O}_{2}$ dissolved in body water was estimated as:

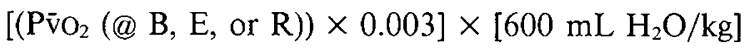
$\times \mathrm{wt}=\mathrm{ml} \mathrm{O}_{2}$ STPD

where $\mathrm{P}_{\overline{\mathrm{v}}} \mathrm{O}_{2}$ was the average mixed venous $\mathrm{PO}_{2}$ during the period designated; 0.003 is the Bunsen solubility coefficient for plasma as defined above. This formula assumes that there is $600 \mathrm{~mL}$ body water $/ \mathrm{kg}$ body wt and that the change in mean tissue $\mathrm{PO}_{2}$ is reflected as a comparable change in $\mathrm{P}_{\overline{\mathrm{V}}}{ }_{2}$.

$\mathrm{O}_{2}$ stores in blood were estimated as:

$$
\begin{gathered}
{\left[\mathrm{CaO}_{2}(@ \mathrm{~B}, \mathrm{E}, \text { or } \mathrm{R})\right] \times 90 \mathrm{~mL} / \mathrm{kg} \times 0.25 \times \mathrm{wt}} \\
+\left[\mathrm{C} \mathrm{vi}_{2}(@ \mathrm{~B}, \mathrm{E}, \text { or } \mathrm{R})\right] \times 90 \mathrm{~mL} / \mathrm{kg} \times 0.75 \times \mathrm{wt} \\
=\mathrm{ml} \mathrm{O} \mathrm{O}_{2} \mathrm{STPD}
\end{gathered}
$$

assuming that the total blood volume of lambs is $90 \mathrm{~mL} / \mathrm{kg}$ and the total blood volume is distributed as if $25 \%$ were arterial and $75 \%$ were venous. We did not measure blood volume or its distribution and this is obviously an estimate. Further, this distribution probably changed during right atrial balloon inflation with more blood pooled in the venous circulation. However, with no better estimate, we assumed the $25 \%$ arterial $-75 \%$ venous distribution for all estimates of changes in blood $\mathrm{O}_{2}$ stores. Changes in blood $\mathrm{O}_{2}$ stores represented the largest change. The net change in $\mathrm{O}_{2}$ stores was determined by summing the changes in stores calculated for lung, tissue water and blood.

Oxygen stores decreased during the change from baseline to low cardiac output because mixed venous $\mathrm{PO}_{2}$ declined thereby decreasing $\mathrm{O}_{2}$ stores in blood and body water even though arterial $\mathrm{PO}_{2}$ increased slightly. We assumed that most of the change in $\mathrm{O}_{2}$ stores occurred during the first $10 \mathrm{~min}$ of low cardiac output because the variables used to estimate stores usually did not change much after that. Oxygen consumption measured at the mouth thus underestimated the true tissue $\mathrm{O}_{2}$ consumption over this time, and the net change in stores was added to the $\mathrm{O}_{2}$ consumption measured at the mouth to determine the true tissue $\mathrm{O}_{2}$ consumption during the first $10 \mathrm{~min}$ of low cardiac output. As $\mathrm{O}_{2}$ stores increased during the change from low cardiac output to recovery, the recovery $\mathrm{O}_{2}$ consumption overestimated tissue $\mathrm{O}_{2}$ consumption. Accordingly, the net change in $\mathrm{O}_{2}$ stores during this transition was subtracted from the $\mathrm{O}_{2}$ consumption measured during the first $10 \mathrm{~min}$ of recovery.

Statistical analysis. Data are reported as mean $\pm 1 \mathrm{SD}$ unless otherwise noted. To compare results from the two age groups, the respective data were compared by $t$ test. Statistical significance was assumed if $p$ was $<0.05$. Oxygen deficit and arterial lactate concentrations at each age were related by linear regres- sion analysis (least squares model). The regression data were compared by analysis of covariance.

\section{RESULTS}

Every lamb had both a 30 - and 60 -min low cardiac output study at both ages. Selected measured and calculated data during baseline conditions are shown in Table 1. These data are comparable to those obtained in other studies from ours and other laboratories $(3,7,11,12)$. The lambs grew normally between studies. $\mathrm{Hb}$ concentration and resting $\mathrm{O}_{2}$ extraction were similar at both ages. Resting cardiac output and $\mathrm{O}_{2}$ consumption showed the expected decline with age (7). Baseline arterial blood lactate concentrations were within normal limits.

There were no significant differences between the 2-wk-old group and the 8-wk-old group in either baseline rectal temperature ( $2 \mathrm{wk}: 40.0 \pm 0.6 \mathrm{C} ; 8 \mathrm{wk}: 40.1 \pm 0.5 \mathrm{C}$ ), ambient temperature ( 2 wk: $24.7 \pm 0.5 \mathrm{C} ; 8 \mathrm{wk}: 24.2 \pm 0.7 \mathrm{C})$, or the difference between rectal and ambient temperature in each study ( $2 \mathrm{wk}$ : $15.3 \pm 0.8 \mathrm{C} ; 8 \mathrm{wk}: 15.9 \pm 0.7 \mathrm{C}$ ). Ambient temperature did not change during the course of a study.

The time course of a single representative experiment for an 8 -wk-old lamb with a 60 -min period of low cardiac output and 60 min of recovery is shown in Figure 1. After a baseline period, the right atrial balloon was inflated at time zero. The cardiac output was acutely decreased to one-third of the resting level and increased after balloon deflation to a level above control. Mean aortic blood pressure was decreased by one-half and increased above baseline during recovery. Accordingly, total systemic vascular resistance increased during low cardiac output and declined after balloon deflation. Core temperature increased slightly during the period of low cardiac output, fell acutely with balloon deflation, and then more gradually decreased to baseline levels. Oxygen consumption was stable during the control period, decreased abruptly (by about $40 \%$ ) during low cardiac output but remained relatively constant at this lower value throughout the period of low cardiac output. Oxygen consumption then increased transiently above the baseline and slowly returned to near baseline values over the 60 -min recovery period. Carbon dioxide production showed a pattern similar to that of $\mathrm{O}_{2}$ consumption, falling slightly less than $\mathrm{O}_{2}$ consumption during low cardiac output (and respiratory exchange ratio increased above 1.0 ), and rising to slightly higher levels during recovery. Extraction increased and was maintained close to $70 \%$ throughout the period of low cardiac output. Arterial blood lactate increased in a linear fashion throughout the period of low cardiac output and more gradually declined during recovery. Arterial-venous differences in $\mathrm{PO}_{2}, \mathrm{pH}, \mathrm{PCO}_{2}$, and $\mathrm{Hb} \mathrm{O}$ saturation widened greatly during the period of low output and recovered quickly when cardiac output was restored. There was no significant change in $\mathrm{Hb}$ concentration during the period of the study.

In general, the same patterns of changes in cardiac output,

Table 1. Comparison of baseline values (mean $\pm S D$ )*

\begin{tabular}{lccc} 
& $\begin{array}{c}\text { 2-wk-old } \\
\text { lambs }\end{array}$ & $\begin{array}{c}\text { 8-wk-old } \\
\text { lambs }\end{array}$ & $\begin{array}{c}\text { Statistical } \\
\text { difference }\end{array}$ \\
\hline $\begin{array}{l}\mathrm{Wt}(\mathrm{kg}) \\
\mathrm{Hb} \text { concentration } \\
(\mathrm{mg} / \mathrm{dL})\end{array}$ & $9.0 \pm 1.8$ & $15.3 \pm 2.7$ & $p=0.001$ \\
$\begin{array}{c}\mathrm{Cardiac} \text { output } \\
(\mathrm{mL} / \mathrm{min} \cdot \mathrm{kg})\end{array}$ & $216 \pm 38$ & $121 \pm 31$ & $p=0.001$ \\
$\begin{array}{c}\mathrm{O}_{2} \text { consumption } \\
(\mathrm{ml} \mathrm{O} / \mathrm{min} \cdot \mathrm{kg})\end{array}$ & $10.3 \pm 2.1$ & $6.7 \pm 1.4$ & $p=0.002$ \\
$\begin{array}{c}\mathrm{O}_{2} \text { extraction } \\
\text { ratio }\end{array}$ & $0.42 \pm 0.09$ & $0.46 \pm 0.06$ & $\mathrm{NS}$ \\
$\begin{array}{c}\text { Arterial lactate } \\
(\mathrm{mmol} / \mathrm{L})\end{array}$ & $0.9 \pm 0.1$ & $1.1 \pm 0.3$ & $p=0.019$ \\
\hline
\end{tabular}

* Groups compared by paired $t$ test. NS, not statistically different ( $p$ $>0.05)$. 

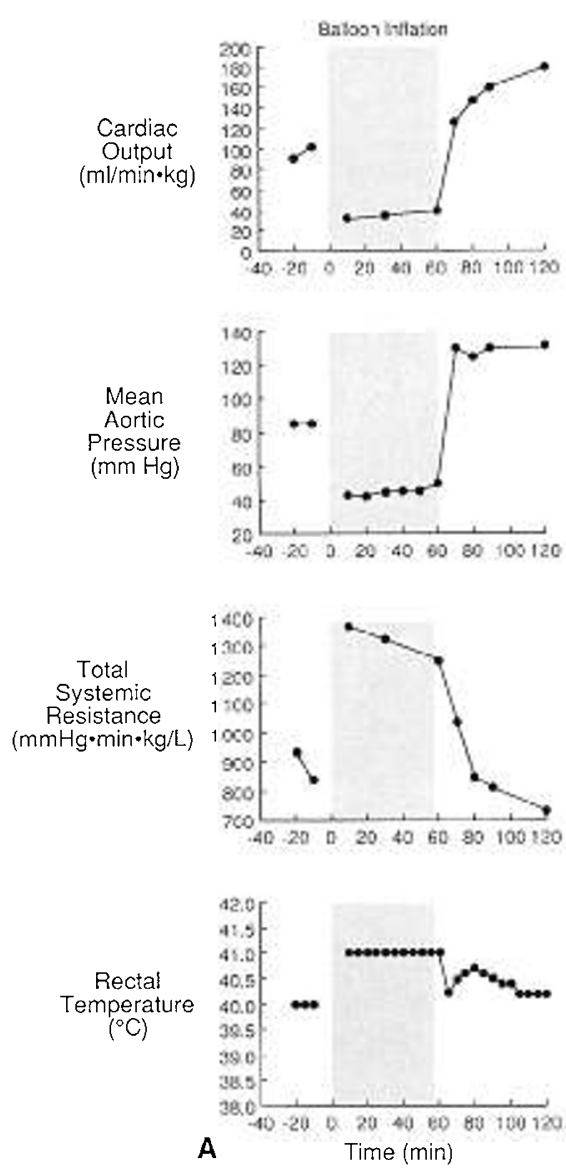
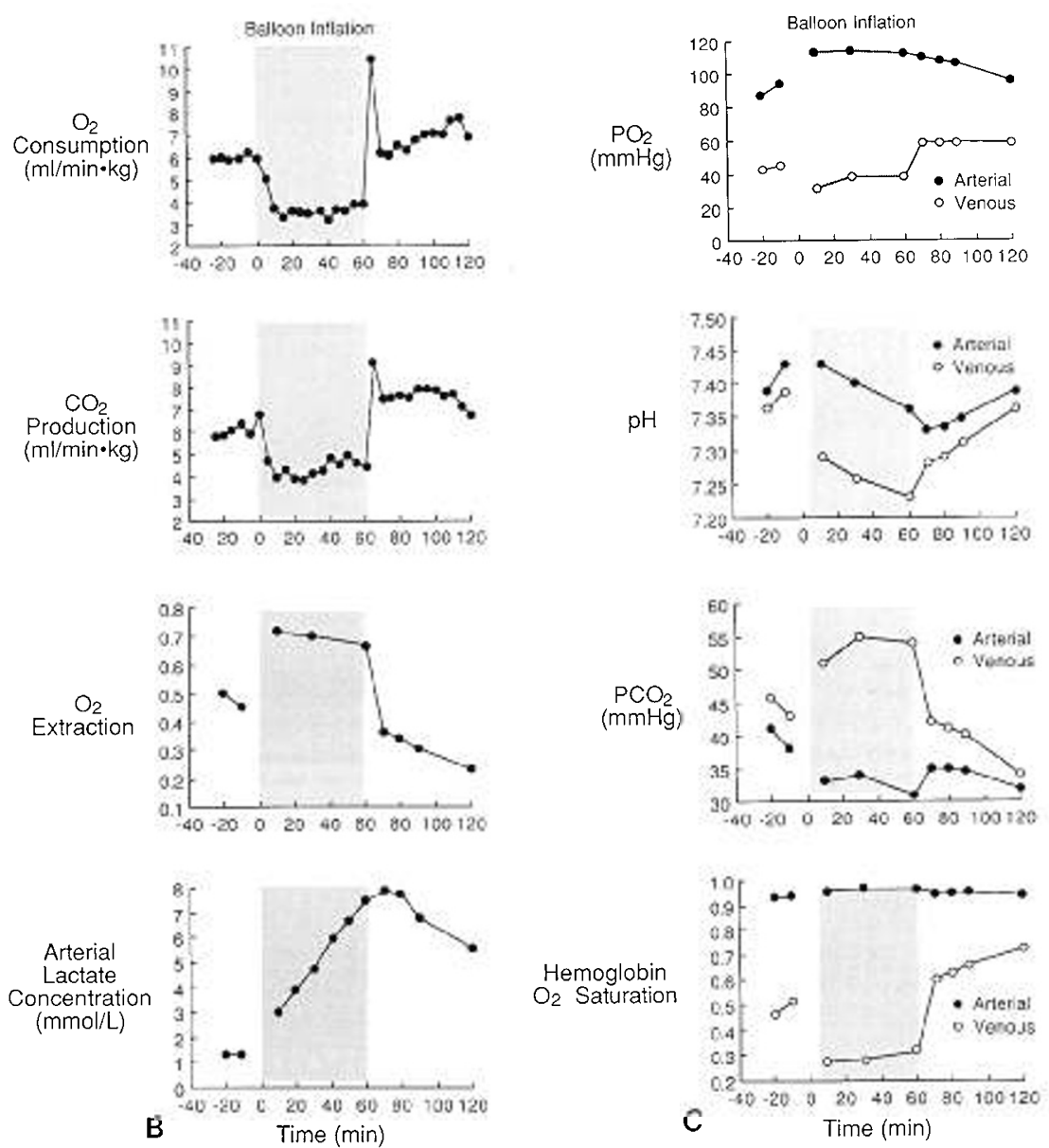

Fig. 1. Changes in hemodynamic $(A)$, metabolic $(A$ and $B)$, and blood gas $(C)$ variables as a function of time during baseline, 60 min of low cardiac output, and $60 \mathrm{~min}$ of recovery. Data are from a single experiment on an 8-wk-old lamb. After a 20 -min baseline period, the right atrial balloon was abruptly inflated at time zero resulting in an acutely lowered cardiac output which was maintained nearly constant. After 60 min, the right atrial balloon was abruptly deflated, allowing recovery.

blood pressure, $\mathrm{O}_{2}$ extraction, blood gases, and arterial lactate as shown in Figure 1 occurred in all studies (30 and $60 \mathrm{~min})$ at both ages. The average percent decreases in cardiac output $(2 \mathrm{wk}$ $66.4 \pm 6.1 \%, 8 \mathrm{wk} 64.6 \pm 4.8 \%)$ and $\mathrm{O}_{2}$ consumption $(2 \mathrm{wk}$ $38.1 \pm 9.3 \%, 8$ wk $35.1 \pm 10.9 \%$ ) during the period of low cardiac output were also similar in the two age groups. However, the patterns of $\mathrm{O}_{2}$ consumption during recovery varied considerably, especially between the two ages.

Figure 2 shows representative studies of a 2-wk-old lamb and an 8-wk-old lamb with changes in $\mathrm{O}_{2}$ consumption during baseline, $30 \mathrm{~min}$ of low cardiac output, and $60 \mathrm{~min}$ of recovery. Oxygen consumption during low output decreased by approximately $33 \%$ in each case. After a rapid, but brief, overshoot above the baseline during recovery, the 2-wk-old lambs often maintained their $\mathrm{O}_{2}$ consumption slightly below baseline during recovery despite having a cardiac output above baseline level. In contrast, the 8-wk-old lambs tended to overshoot the baseline during recovery and then maintain their $\mathrm{O}_{2}$ consumption above the baseline. Thus, despite comparable disruptions in $\mathrm{O}_{2}$ supply, these differences in the patterns of recovery of the two groups, as shown in Figure 2, were a consistent finding.

These age-related differences in $\mathrm{O}_{2}$ consumption during recovery are shown in Figure 3, where excess $\mathrm{O}_{2}$ consumption during recovery $\left(\mathrm{O}_{2}\right.$ recovery $)$ is plotted as a function of the total $\mathrm{O}_{2}$ deficit accumulated $\left(\mathrm{O}_{2}\right.$ deficit) for each experiment. It is apparent that during most studies there was little or no excess $\mathrm{O}_{2}$ consumption during recovery of the 2 -wk-old lambs. In fact, in four of the five 60 -min studies, representing the largest $\mathrm{O}_{2}$ deficits, the $\mathrm{O}_{2}$ consumption was lower during recovery than during baseline and the net "payback" was negative. For the 2-wk-old group, the excess $\mathrm{O}_{2}$ consumption of recovery averaged $3 \pm 16 \%$ (mean $\pm \mathrm{SEM}$ ) of the deficit. Although there is substantial scatter in the older group, there is considerably more excess $\mathrm{O}_{2}$ consumption during recovery in these studies, an average of $76 \pm$ $29 \%$ of the deficit. In neither age group was there any obvious relation between $\mathrm{O}_{2}$ recovery and $\mathrm{O}_{2}$ deficit.

Inasmuch as $\mathrm{O}_{2}$ consumption remained relatively constant during low cardiac output, $\mathrm{O}_{2}$ deficit increased linearly as a function of time in each study. Similarly arterial lactate concentration increased linearly as a function of time and these two variables were closely correlated for both individual lambs and also for grouped data. The relationship of arterial lactate concentration to accumulating $\mathrm{O}_{2}$ deficit is shown in Figure 4. The 30 and 60 -min data from all studies are shown, again grouped by age. A linear correlation can be seen for both groups. The slope of the relationship in the 8-wk-old lambs was the same as we have reported in 2-mo-old lambs under comparable conditions (3). However, this slope was significantly greater $(p<0.01$, by ANOVA) than that found for the younger lambs.

In every study, lactate decreased progressively with time during recovery, usually in a linear fashion. This was true even in those 2-wk-old lambs whose $\mathrm{O}_{2}$ consumption was below baseline during recovery and whose net $\mathrm{O}_{2}$ payback was negative. There was no obvious correlation between lactate concentration and excess $\mathrm{O}_{2}$ consumption of recovery in either age group.

\section{DISCUSSION}

It was the aim of our study to make comparable disruptions in whole body $\mathrm{O}_{2}$ metabolism in lambs at two different ages 

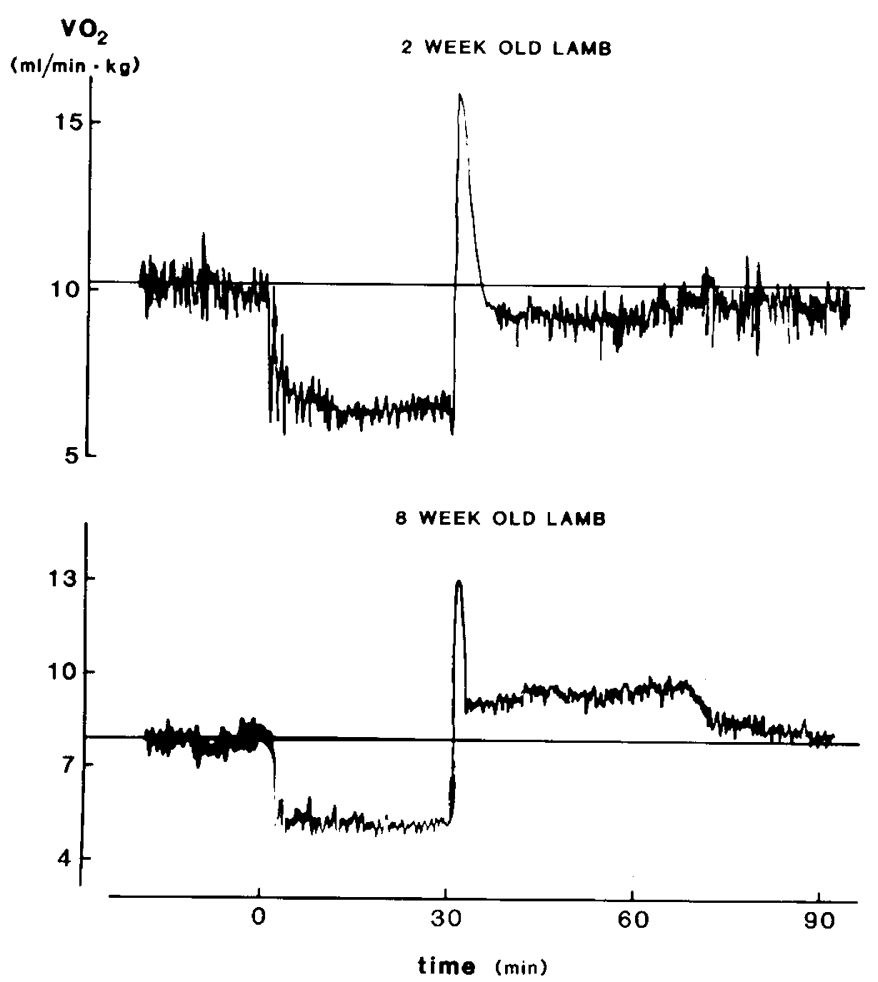

Fig. 2. Representative studies of a 2-wk-old lamb (top) and an 8-wkold lamb (bottom) showing changes in $\mathrm{O}_{2}$ consumption $\left(\mathrm{VO}_{2}\right)$ during baseline, $30 \mathrm{~min}$ of low cardiac output, and $60 \mathrm{~min}$ of recovery. The extrapolated baseline is superimposed on the tracings. After an initial increase in $\mathrm{O}_{2}$ consumption during recovery, the 2-wk-old lambs tended to maintain their $\mathrm{O}_{2}$ consumption below baseline whereas the 8 -wk-olds tended to maintain $\mathrm{O}_{2}$ consumption above baseline.

which have very different basal $\mathrm{O}_{2}$ requirements (Table 1). We used the calculated $\mathrm{O}_{2}$ deficit as a common measure of $\mathrm{O}_{2}$ lack during the low cardiac output period to compare the metabolic responses during the low cardiac output and recovery in the two age groups. We chose the level of reduction in cardiac output based on previous studies $(3,12)$ to be sure that: 1$)$ it would be well below the critical level of $\mathrm{O}_{2}$ delivery, 2) lactate would be produced, and 3 ) this state would be tolerated for periods up to $60 \mathrm{~min}$. To ensure that the disruptions were comparable, in every study at both ages, we acutely decreased cardiac output so that the whole body $\mathrm{O}_{2}$ consumption was reduced by one third $(38.1 \%$ decrease at $2 \mathrm{wk}$ and $35.1 \%$ decrease at $8 \mathrm{wk}$ ) with respect to baseline and was maintained at a nearly steady state. Fortuitously, these reductions in $\mathrm{O}_{2}$ consumption occurred with similar proportional decreases in cardiac output $(66.4 \%$ decrease at 2 wk and $64.6 \%$ decrease at $8 \mathrm{wk}$ ). Inasmuch as $\mathrm{Hb}$ concentration and arterial $\mathrm{O}_{2}$ saturation did not change significantly during the low cardiac output period, systemic $\mathrm{O}_{2}$ delivery (= cardiac output $\times$ arterial $\mathrm{O}_{2}$ content) varied directly with cardiac output. The decreases in $\mathrm{O}_{2}$ consumption in the two groups therefore occurred with similar reductions in $\mathrm{O}_{2}$ delivery as well. Thus, with these similar perturbations in $\mathrm{O}_{2}$ consumption and supply at the two ages studied, we presume that differences that we detected in the metabolic responses during low cardiac output and recovery were primarily developmental differences.

We used ketamine at a constant infusion rate to sedate the lambs and minimize large variations in $\mathrm{O}_{2}$ consumption associated with agitation or in response to disturbances during the study. In particular, we wanted to establish the most stable baseline $\mathrm{O}_{2}$ consumption possible as this was crucial in determining the $\mathrm{O}_{2}$ deficit and excess $\mathrm{O}_{2}$ consumption of recovery (see Fig. 2). Ketamine stimulates the cardiovascular system through both central and peripheral mechanisms, resulting in increases in heart rate, cardiac output and arterial blood pressure,
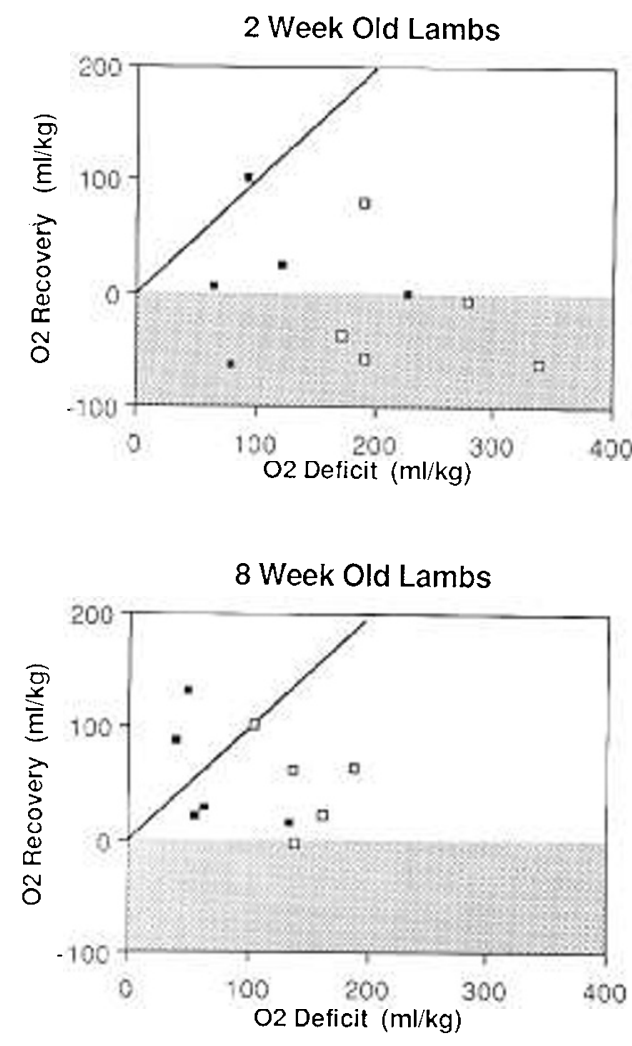

- 30 min. low $Q$ - $60 \mathrm{~min}$. low $Q$

Fig. 3. Excess $\mathrm{O}_{2}$ of recovery $\left(\mathrm{O}_{2}\right.$ recovery) is plotted in relation to $\mathrm{O}_{2}$ deficit $\left(\mathrm{O}_{2}\right.$ deficit) for the 2-wk-old (top) and 8-wk-old (bottom) lambs. The 30 -min studies are shown by solid squares and the 60 -min studies by open squares. The line of identity is shown for reference in each panel. Points in the shaded area represent studies in which mean $\mathrm{O}_{2}$ consumption during recovery was less than that during baseline, i.e. there was no net excess $\mathrm{O}_{2}$ of recovery.

with no change in systemic vascular resistance $(13,14)$. We could find no reports of any age-related differences in the cardiovascular stimulant properties of ketamine. Further, ketamine does not change resting whole body $\mathrm{O}_{2}$ consumption in adult dogs (15). We routinely monitored $\mathrm{O}_{2}$ consumption during the administration of ketamine and found decreases in the variations in $\mathrm{O}_{2}$ consumption but no consistent changes in the mean level of $\mathrm{O}_{2}$ consumption. Ketamine anesthesia resulted in slightly higher levels of arterial blood lactate concentration during acute blood loss (up to $30 \%$ of estimated blood volume) in adult dogs when compared to inhalational anesthetic agents (15). Unfortunately, no dogs were studied without any anesthesia, so it is impossible to determine if the lactate levels with ketamine were higher than expected, or whether the lactate levels were lower than expected with the inhalational agents during this degree of hemorrhage. Again, we could find no studies indicating a differential effect with age on lactate metabolism. Thus, although ketamine may have affected the level of lactate concentration during the low output period (16), we do not believe that it had any effect on the age-related differences we found.

We could not discern any relationship between $\mathrm{O}_{2}$ deficit and excess $\mathrm{O}_{2}$ of recovery in either age group (Fig. 3) nor have others in studies of adult dogs during either stagnant hypoxia (6) or nypoxic hypoxia $(2,4,5)$. We found, as did these earlier studies, that $\mathrm{O}_{2}$ "repayment" (excess $\mathrm{O}_{2}$ of recovery) was usually less than the deficit. This observation has led to the thesis that the portion of the deficit not repaid during recovery (in the presence of adequate $\mathrm{O}_{2}$ availability) represents facultative, or nonessential, $\mathrm{O}_{2}$ metabolism (5). Facultative metabolism thus represents processes requiring $\mathrm{O}_{2}$ that are a part of normal metabolism but are not essential for survival (16). These processes are thought to be 


\section{Week Old Lambs}

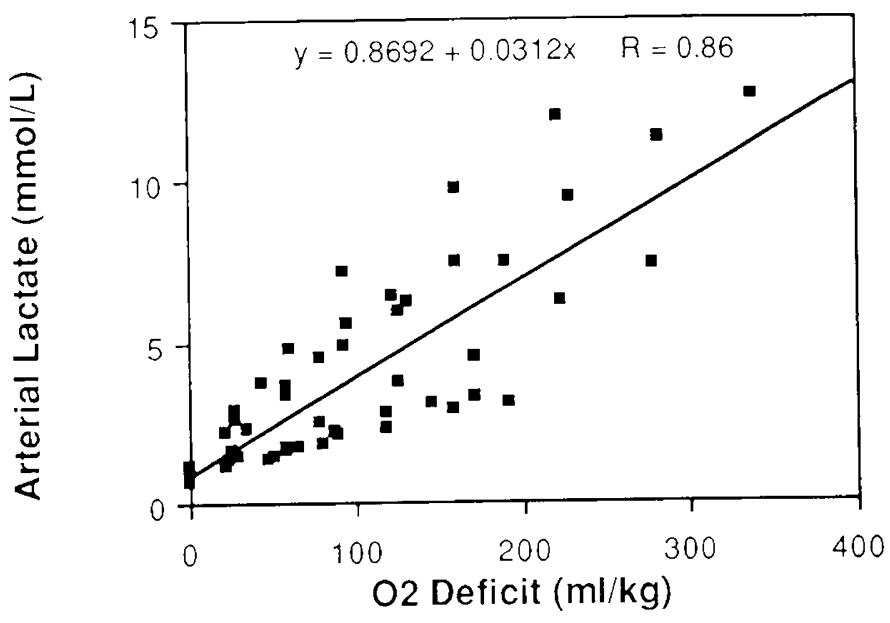

8 Week Old Lambs

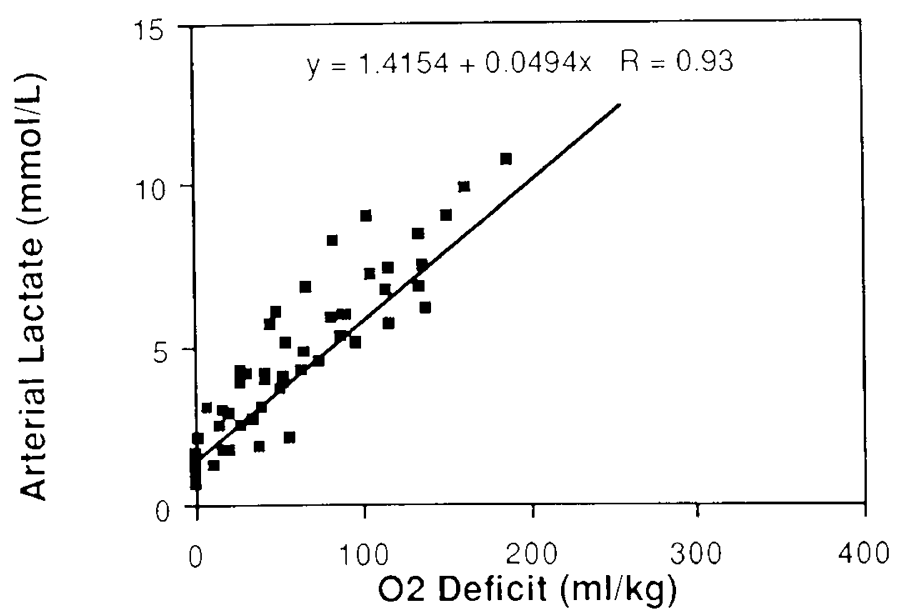

Fig. 4. Arterial blood lactate concentration shown as a function of accumulating $\mathrm{O}_{2}$ deficit. Data from all studies are included, graphed by age. The linear regression line for the grouped data is superimposed.

largely extramitochondrial, to occur in various intracellular compartments, and to regulate the degradation, detoxification, or biosynthesis of a number of molecular species (16-18). The extramitochondrial functions are assumed to have a lower affinity for $\mathrm{O}_{2}$ than the cytochrome oxidase system and, as $\mathrm{O}_{2}$ becomes limited, their activity would decrease before the more essential enzyme systems involved in oxidative phosphorylation. Energy used for growth, other anabolic processes, and thermoregulation are other potential examples of nonessential metabolism (11). During a period of limited $\mathrm{O}_{2}$ transport, decreases of organ $\mathrm{O}_{2}$ demand by reduction of nonessential metabolism might allow relatively normal organ function, at least over the short term, by maintaining mitochondrial $\mathrm{O}_{2}$ supply, thereby sustaining cellular energy stores and decreasing the need for anaerobic metabolism. It is not known whether these facultative processes are altered before or simultaneous with the more essential metabolic processes during conditions of limited $\mathrm{O}_{2}$ supply. Nor is it established what factors regulate such strategic metabolic choices $(5,11,16)$.

In our studies, we would expect that at least part of the fall in tissue $\mathrm{O}_{2}$ consumption during the low cardiac output period is attributable to a decline in nonessential metabolism as a means of compensation for the decreased $\mathrm{O}_{2}$ delivery. However, any decrease in the $\mathrm{O}_{2}$ demands by loss of facultative metabolism means that extrapolation of the baseline $\mathrm{O}_{2}$ consumption through the low output period overestimates the basal $\mathrm{O}_{2}$ requirements, which would have shifted to a lower value. The $\mathrm{O}_{2}$ deficit as we have calculated it would correspondingly overestimate the "true" debt for $\mathrm{O}_{2}$ (as nonessential metabolism would not require "repayment"). Any difference between the calculated deficit and the actual excess $\mathrm{O}_{2}$ of recovery would provide an estimate of decreased energy requirements (16). In other words, the larger the decline in $\mathrm{O}_{2}$ demands, the more the calculated $\mathrm{O}_{2}$ deficit will overestimate the "true" debt, and the smaller the fraction of the calculated deficit that will require "payback." It would be expected that young, growing animals (and humans) would have higher proportions of nonessential metabolism and that this would be a more important mechanism for compensation of decreased $\mathrm{O}_{2}$ delivery in these subjects. Our observation that the younger group of lambs "paid back" a significantly smaller fraction $(0.03 \pm 0.16)$ of their deficit as compared to the older group $(0.76 \pm 0.29)$ is in accord with this hypothesis. As estimated by Sidi et al. (12), 30-35\% of $\mathrm{O}_{2}$ consumption in the newborn lamb is used for growth, whereas this decreases to about $10 \%$ by $6 \mathrm{wk}$ of age. Further evidence in support of this concept is the finding that the 2-wk-old lambs accumulated lactate at a significantly lower rate than the older lambs (slope of lines in Fig. 4) for comparable levels of accumulating deficit.

It is also important to note that in the young lambs $\mathrm{O}_{2}$ consumption remained below baseline in the majority of the studies during recovery. This implies that there was a continued decrease in the $\mathrm{O}_{2}$ demands during part of recovery in this age group even though core temperature was not decreased, cardiac output was restored and lactate was metabolized. This low $\mathrm{O}_{2}$ consumption in the young lambs suggests that facultative and total metabolism remained depressed during at least part of recovery and this potentially represents an important mechanism in the recovery process for this age group. It also demonstrates that it may take a prolonged time for metabolism to be restored despite augmentation of perfusion.

Although we have presumed that a large part of the change in basal $\mathrm{O}_{2}$ demands during low output was due to changes in nonessential metabolism, there are other factors that must be considered in this experimental model. Basal $\mathrm{O}_{2}$ demands could also have been altered by changes in cardiopulmonary work, changes in core temperature, or changes in catecholamine concentrations (stimulating thermogenesis), any of which could make extrapolation of the baseline through the low output period inaccurate. We did not measure cardiorespiratory work directly, but can make some reasonable estimates. The metabolic expenditure for respiration in normal adult and young subjects at rest is generally estimated to be $5 \%$ or less of the whole body $\mathrm{O}_{2}$ consumption $(19,20)$. Arterial $\mathrm{PCO}_{2}$ decreased in all lambs during the low cardiac output period (Fig. 1), presumably as a controlled respiratory response to the lactic acidosis. We initially assumed that the lowered arterial $\mathrm{PCO}_{2}\left(\mathrm{PaCO}_{2}\right)$ would be the result of increased alveolar ventilation and therefore increased work of breathing. However, it occurred to us that total $\mathrm{CO}_{2}$ production decreased simultaneously and that alveolar ventilation may not have to increase much to achieve the lower arterial $\mathrm{PCO}_{2}$ (because alveolar ventilation is proportional to $\mathrm{CO}_{2}$ production/ $/ \mathrm{PaCO}_{2}$ ) (21). In fact, $\mathrm{CO}_{2}$ production decreased (to $70 \%$ of baseline) proportionally more than $\mathrm{PaCO}_{2}$ (to $83 \%$ of baseline) during the low output period and changes were similar in both age groups. Thus, alveolar ventilation actually decreased to $84 \%$ of baseline and respiratory work and $\mathrm{O}_{2}$ consumption would presumably have decreased in proportion. Resting myocardial metabolism in lambs represents about $10 \%$ of whole body $\mathrm{O}_{2}$ consumption (22). In both age groups, systolic (and mean) arterial blood pressure decreased relatively more ( $45 \%$ decrease) than heart rate increased ( $7 \%$ increase) during the low cardiac periods. We 
estimated changes in myocardial $\mathrm{O}_{2}$ consumption by calculating changes in the rate-pressure product (heart rate $\times$ peak systolic aortic pressure) and found that myocardial $\mathrm{O}_{2}$ consumption would have decreased by approximately $41 \%$ in both age groups. Therefore, we estimate that cardiopulmonary $\mathrm{O}_{2}$ consumption decreased during the low output period; this would cause extrapolation of baseline $\mathrm{VO}_{2}$ to be an overestimate (by about $7 \%$ ) of $\mathrm{O}_{2}$ demands during low cardiac output.

The effects of thermogenesis on $\mathrm{O}_{2}$ demands during low cardiac output are much less predictable and cannot be quantified. We have no estimate of mean body temperature but increases in core temperature were always less than $1^{\circ} \mathrm{C}$, were similar in both age groups, and should not have contributed significantly to changes in basal demands during low output. Furthermore, ambient temperature did not change during the studies and was similar for both age groups. Thus, a differential response to ambient temperature could not have accounted for the observed changes in $\mathrm{O}_{2}$ consumption during the low output period. We did not measure serum catecholamine concentrations nor can we estimate how much calorigenesis was stimulated by changes in their concentrations. However, data from other studies in which $\beta$-adrenergic blockade was used to ablate the calorigenic effects of catecholamines during hypoxia suggest that this could increase $\mathrm{O}_{2}$ consumption by about $10 \%(23,24)$. We have no evidence that the influence of these thermogenic factors was different for the two age groups, although age-related differences in catecholamine stimulation or metabolic responsiveness during low cardiac output has not been studied to our knowledge. Therefore, although there were factors during low cardiac output that could have increased (temperature changes, catecholamines) or decreased (cardiopulmonary work) $\mathrm{O}_{2}$ demands compared to baseline, the net effect was small and the extrapolation of baseline $\mathrm{O}_{2}$ consumption was probably reasonable for both age groups.

We attempted to make steady state changes in $\mathrm{O}_{2}$ consumption and cardiac output. This allowed us to correct for changes in body stores of $\mathrm{O}_{2}$ and to consider time as a factor in $\mathrm{O}_{2}$ deficit accumulation. As seen in the example in Figure 1, our model did establish a steady state in terms of blood pressure, cardiac output, and whole body $\mathrm{O}_{2}$ consumption and $\mathrm{CO}_{2}$ production, but not for arterial lactate concentration. Blood lactate concentration increased linearly with both time and $\mathrm{O}_{2}$ deficit in all studies and never reached a plateau during low output. A linear relationship between arterial lactate concentration and time (as well as $\mathrm{O}_{2}$ deficit) has been reported previously for both stagnant hypoxia (3) and hypoxia $(3,23,25)$. The use of lactate concentration as a marker of "tissue hypoxia" is controversial (26-28). It has been traditional to attribute lactic acidemia to overproduction of lactic acid by hypoxic tissues; however, lactate accumulation is more accurately viewed as the balance between increased production rates and decreased removal rates (26-28). Although we measured neither lactate production nor lactate use in our studies, we would expect that the lactate accumulation we detected is caused by both increased production and decreased removal rates $(3,26-28)$. With the large decreases in whole body $\mathrm{O}_{2}$ consumption and cardiac output we produced, it is likely that some tissues, e.g. the respiratory muscles and skeletal muscle (29, 30 ) increased their production of lactate. Concomitantly, hepatic lactate clearance $(31,32)$ and whole body net elimination of lactate $(27,33,34)$ were probably diminished.

We also found that the increase in lactate concentration per increase in $\mathrm{O}_{2}$ deficit (slope of the lines in Fig. 4) was significantly different between the two age groups, with the younger lambs having lower lactate levels at any given deficit. One explanation for this is that the lactate production rates were lower in this age group, reflecting better use of the available $\mathrm{O}_{2}$ and less anaerobic metabolism (although there was no age-related difference in the fractional $\mathrm{O}_{2}$ extraction during low cardiac output). This explanation would be in keeping with our hypothesis of a proportionally larger decline in nonessential metabolism in the younger age group. However, alternative explanations must be considered. It may be that the lactate production rates were similar in the two age groups but the younger lambs were better able to metabolize the lactate load. The newborn liver and kidneys may have had higher fractional extractions of lactate or were able to maintain lactate metabolism in spite of decreases in blood flow and $\mathrm{O}_{2}$ delivery. Alternatively, it may have been that there were differences in the distribution of blood flow during low output between the two age groups. For example, if the liver blood flow in the 2wk-old lambs did not fall proportionately as much as in the older lambs, more lactate would have been delivered to the liver for removal in the younger age group. Higher removal rates in the younger group would have resulted in lower accumulation rates even if production rates were the same. We are currently undertaking further studies in our laboratory to determine lactate production and removal rates and sort out this interesting question.

To summarize, we found no obvious relationship between the excess $\mathrm{O}_{2}$ of recovery and the $\mathrm{O}_{2}$ deficit in either age group studied. However, our data show that, in contrast to older subjects, there was little or no "repayment" of an $\mathrm{O}_{2}$ deficit in young lambs after a prolonged period of low cardiac output. Furthermore, lactate accumulated slower in the young lambs and was metabolized during recovery even in those lambs in which there was no excess $\mathrm{O}_{2}$ consumption. We speculate that during a period of very low cardiac output, the young subject not only decreases its $\mathrm{O}_{2}$ consumption but also decreases its metabolic demands by suppression of some or all of its nonessential $\mathrm{O}_{2}$ metabolism. Cellular processes were diminished with minimal use of energy stores that needed to be replenished. This is in contrast to the older subject under comparable conditions. This may provide a mechanism for the greater tolerance in the newborn and young subject for such an hypoxic insult.

Acknowledgments. The authors thank Andrea O. Ray for her expert technical assistance and Lisa M. DeLizio for her assistance in the preparation of the manuscript.

\section{REFERENCES}

1. Alpert NR 1952 Effect of acute cardiac tamponade upon respiratory metabolism in the dog. Am J Physiol 168:565-574

2. Cain $\mathrm{SM} 1967 \mathrm{O}_{2}$ deficit incurred during hypoxia and its relation to lactate and excess lactate. Am J Physiol 213:57-63

3. Moss M, Kurzner S, Razlog Y, Lister G 1988 Hypoxanthine and lactate concentrations in lambs during hypoxic and stagnant hypoxia. Am J Physiol 255:H53-H59

4. Alpert NR, Kayne H, Haslett W 1958 Relationship among recovery oxygen, oxygen missed, lactate production and lactate removal during and following severe hypoxia in the unanesthetized dog. Am J Physiol 192:585-591

5. Adams RP, Cain SM 1983 Total and hind limb oxygen deficit and "repayment" in hypoxic anesthetized dogs. J Appl Physiol 55:913-922

6. Alpert NR 1965 Lactate production and removal and the regulation of metabolism. Ann NY Acad Sci 199:955-1012

7. Lister G, Walter TK, Versmold HT, Dallman PR, Rudolph AM 1979 Oxygen delivery in lambs: cardiovascular and hematologic development. Am J Physiol 237:H668-H675

8. Fahey JT, Lister G 1985 A simple method for reducing cardiac output in the conscious lamb. Am J Physiol 249:H188-H192

9. Lister G, Hoffman JIE, Rudolph AM 1974 Oxygen uptake in infants and children. A simple method for measurement. Pediatrics 53:656-662

10. Sigma Chemical Co. 1980 Enzymatic Determination of L(+) Lactate in Blood or Plasma at $340 \mathrm{~nm}$. St. Louis, MO, 1980 (Tech. Bull. No. 826-UV)

11. Sidi D, Kuipers JRG, Teitel D, Heymann MA, Rudolph AM 1983 Developmental changes in oxygenation and circulatory response to hypoxemia in lambs. Am J Physiol 245:H674-H682

12. Fahey JT, Lister G 1987 Postnatal changes in critical cardiac output and $\mathrm{O}_{2}$ transport in conscious lambs. Am J Physiol 253:H100-H106

13. White PF, Way WL, Trevor AJ 1982 Ketamine-its pharmacology and therapeutic uses. Anesthesiology 56:119-136

14. Warren TM, Stoelting RK 1986 Hemodynamic effects of general anesthesia In: Altura BM, Halevy S (eds) Cardiovascular Actions of Anesthetics and Drugs Used in Anesthesia, 1. Basic Aspects, Karger, New York, pp 30-34

15. Weiskopf RB, Townsley MI, Riordan KK, Chadwick K, Baysinger M, Mahoney $\mathrm{E} 1981$ Comparison of cardiopulmonary responses to graded hemorrhage during enflurane, halothane, isoflurane, and ketamine anesthesia. Anesth Analg 60:481-491

16. Robin ED 1980 Of men and mitochondria: Coping with hypoxia dysoxia. Am Rev Respir Dis 122:517-531 
17. Block K 1962 Oxygen and biosynthetic patterns. Fed Proc 21:1058-1063

18. Robin ED 1978 Overview, dysoxia-abnormalities of tissue oxygen use. In Lenfant $C$ (ed) Extrapulmonary Manifestations of Respiratory Disease. Marcel Dekker, New York, pp 3-12

19. Field S, Kelly SM, Macklem PT 1982 The oxygen cost of breathing in patient with cardiorespiratory disease. Am Rev Respir Dis 126:9-13

20. Cameron CB, Gregory GA, Rudolph AM, Haymann MA 1986 Cardiovascular effects of $d$-tubocurarine and pancuronium in newborn lambs during normoxia and hypoxia. Pediatr Res 20:246-252

21. Rahn H, Fenn WO $1955 \mathrm{~A}$ graphical analysis of the respiratory gas exchange. The American Physiological Society, Washington, DC, pp 39-40

22. Berman W Jr, Lister G, Alverson D, Olsen S 1987 Ouabain effects on oxygen physiology in anemic lambs. Pediatr Res 21:447-452

23. Cain SM 1969 Diminution of lactate rise during hypoxia by $\mathrm{PCO}_{2}$ and $\mathrm{B}-$ adrenergic blockade. Am J Physiol 217:110-116

24. Cain SM 1983 Peripheral oxygen uptake and delivery in health and disease. Clinics in Chest Medicine 4:139-148

25. Cain SM 1973 Relative rates of arterial lactate and oxygen deficit accumulation in hypoxic dogs. Am J Physiol 224:1190-1194

26. Fahey J, Lister G 1987 Oxygen transport in low cardiac output states. J Crit
Care 2:288-305

27. Eldridge FL 1974 Relationship between lactate turnover rate and blood concentration in hemorrhagic shock. J Appl Physiol 37:321-323

28. Cohen RD, Woods HF 1983 Lactic acidosis revisited. Diabetes 32:181-191

29. Aubier M, Viires N, Syllie G, Mozes R, Roussos Ch 1982 Respiratory muscle contribution to lactic acidosis in low cardiac output. Am Rev Respir Dis 126:648-652

30. Viires N, Sillye G, Aubier M, Rassidakis A, Roussos Ch 1983 Regional blood flow distribution in dog during induced hypotension and low cardiac output. $\mathrm{J}$ Clin Invest 72:935-947

31. Berry MN, Scheuer J 1967 Splanchnic lactic acid metabolism in hyperventilation, metabolic alkalosis and shock. Metabolism 16:537-546

32. Schroder R, Gumpert JRW, Pluth JR, Eltringham WK, Jenny ME, Zollinger RM 1969 The role of the liver in the development of lactic acidosis in low flow states. Postgrad Med J 45:566-570

33. Wiener R, Spitzer JJ 1974 Lactate metabolism following severe hemorrhage in the conscious dog. Am J Physiol 227:58-62

34. Daniel AM, Pierce CH, MacLean LD, Shizgal HM 1976 Lactate metabolism in the dog during shock from hemorrhage, cardiac tampoade or endotoxin. Surg Gynecol Obstet 143:581-586 